\title{
Correlation between flow cytometry and histologic findings: ten year experience in the investigation of lymphoproliferative diseases
}

\author{
Correlação entre citometria de fluxo e anatomia patológica: experiência de dez \\ anos na investigação de doenças linfoproliferativas
}

\begin{abstract}
Alanna Mara Pinheiro Sobreira Bezerra ${ }^{1}$, Denise da Cunha Pasqualin ${ }^{1}$, João Carlos de Campos Guerra ${ }^{2}$, Marjorie Paris Colombini $^{3}$, Elvira Deolinda Rodrigues Pereira Velloso ${ }^{2}$, Paulo Augusto Achucarro Silveira ${ }^{2}$, Cristovão Luis Pitangueira Mangueira $^{1}$, Ruth Hissae Kanayama ${ }^{3}$, Sonia Tsukasa Nozawa ${ }^{3}$, Rodolfo Correia ${ }^{3}$, Ana Carolina Apelle ${ }^{1}$, Welbert de

Oliveira Pereira ${ }^{3}$, Rodrigo Gobbo Garcia ${ }^{4}$, Nydia Strachman Bacal ${ }^{5}$
\end{abstract}

\begin{abstract}
Objective: To demonstrate the advantages of correlating flow cytometry immunophenotyping with the pathology/ immunohistochemistry of lymph nodes or nodules in the diagnosis of lymphoproliferative diseases. Methods: A retrospective study was carried out of 157 biopsy or fine-needle aspiration lymph nodes/ nodule specimens taken from 142 patients, from 1999 and 2009. The specimens were simultaneously studied with flow cytometry and pathology at Hospital Israelita Albert Einstein. The specimens were prepared in hematoxylin/eosin, Giemsa, or monoclonal antibody stained slides for detecting specific antibodies for the purposes of pathology/immunohistochemical analysis. The samples were hemolyzed and marked with different monoclonal antibody panels for different antigens in flow cytometry immunophenotyping. Results: The diagnostic results of pathology/immunohistochemical studies and flow cytometry immunophenotyping agreed in 115 patients $(81 \%)$, corresponding to 127 specimens, as follows according to the pathologic diagnosis: 63 patients with non-Hodgkin's B-cell lymphoma; 26 patients with reactive lymphoid hyperplasia; 5 patients with non-Hodgkin's T-cell lymphoma; 4 patients with atypical lymphoid proliferation; 5 patients with a chronic granulomatous inflammatory process; 5 patients with a non-hematologic diagnosis; 2 patients with granulocytic sarcoma; 2 patients with thymoma; 1 patient with byphenotypic leukemia; 1 patient with kappa plasmocytoma; 1 patient with Hodgkin's lymphoma. Subtypes of lymphomas could be classified by associating the two techniques: 19 patients with
\end{abstract}

follicular lymphoma; 15 patients with diffuse large B-cell lymphoma; 7 patients with small lymphocytic B-cell lymphoma/chronic lymphocytic leukemia; 3 patients with mantle cell lymphoma; 1 patient with Burkitt's lymphoma; 1 patient with MALT type lymphoma; 1 patient with post-transplant lymphoproliferative disease; 2 patients with high grade non-Hodgkin's B-cell lymphoma; 1 patient with low grade nonHodgkin's B-cell lymphoma not otherwise specified; 1 patient with Hodgkin's lymphoma; and 12 patients with B-cell non-Hodgkin's lymphoma not otherwise specified. Conclusion: Flow cytometry adds to the results of morphologic and immunohistochemical studies, facilitating a rapid and accurate diagnosis of lymphoproliferative diseases.

Keywords: Lymphoma; Lymphoproliferative disorders/diagnosis; Immunophenotyping; Flow cytometry; Immunohistochemistry

\section{RESUMO}

Objetivo: Evidenciar as vantagens da correlação entre imunofenotipagem porcitometria de fluxo e exame anatomopatológico/ imunoistoquímico de adenomegalias e/ou nódulos no diagnóstico de doenças linfoproliferativas. Métodos: Estudo retrospectivo no qual foram avaliadas 157 amostras de biópsias ou punções aspirativas de gânglios ou nódulos de 142 pacientes, durante o período de 1999 a 2009. As amostras tinham sido encaminhadas simultaneamente para os Serviços de Citometria de Fluxo e Anatomia Patológica do Hospital

\footnotetext{
Study carried out at Hospital Israelita Albert Einstein - HIAE - São Paulo (SP), Brazil.

1 Pathological Anatomy - Department of Clinical Pathology, Hospital Israelita Albert Einstein - HIAE - São Paulo (SP), Brazil.

${ }^{2}$ Hematology, Department of Clinical Pathology, Hospital Israelita Albert Einstein - HIAE - São Paulo (SP), Brazil.

${ }^{3}$ Clinical Pathology Department, Hospital Israelita Albert Einstein - HIAE - São Paulo (SP), Brazil.

${ }^{4}$ Department of Imaging, Hospital Israelita Albert Einstein - HIAE - São Paulo (SP), Brazil.

${ }^{5}$ Division of Flow Cytometry, Department of Clinical Pathology, Hospital Israelita Albert Einstein - HIAE - São Paulo (SP), Brazil.

Corresponding author: Nydia Strachman Bacal - Division of Flow Cytometry, Department of Clinical Pathology, Hospital Israelita Albert Einstein - HIAE - Avenida Albert Einstein, 627/701 - Morumbi - CEP 05651-901 - São Paulo (SP), Brasil - e-mail: nsbacal@einstein.br

Received on: Mar 29, 2011 - Accepted on : May 20, 2011

Conflict of interest: none
} 
Israelita Albert Einstein, em São Paulo. Para a análise na anatomia patológica, as amostras foram preparadas em lâminas e coradas com hematoxilina-eosina, Giemsa, ou marcadas com anticorpos monoclonais para detecção de antígenos específicos. Para a análise por imunofenotipagem por citometria de fluxo, as amostras foram hemolisadas e marcadas com diferentes painéis de anticorpos monoclonais para detecção dos diferentes antígenos. Resultados: Foram concordantes os diagnósticos entre a anatomopatológico e imunofenotipagem por citometria de fluxo em 115 (81\%) pacientes, o que correspondeu a 127 amostras distribuídas da seguinte forma, conforme 0 diagnóstico anatomopatológico: 63 pacientes com linfoma não Hodgkin de células $B ; 26$ pacientes com hiperplasia linfoide reacional; 5 pacientes com linfoma não Hodgkin de células $T ; 4$ pacientes com proliferação linfoide atípica; 5 pacientes com processo inflamatório crônico granulomatoso; 5 pacientes com diagnósticos não hematológicos; 2 pacientes com sarcoma granulocítico; 2 pacientes com timoma; 1 paciente com leucemia bifenotípica; 1 paciente com plasmocitoma Kappa; e 1 paciente com linfoma de Hodgkin. A correlação entre os resultados das duas técnicas permitiu a classificação dos subtipos de linfomas da seguinte forma: 19 pacientes com linfoma folicular; 15 pacientes com linfoma difuso de grandes células $B ; 7$ pacientes com linfoma linfocítico de pequenas células B/leucemia linfocítica crônica; 3 pacientes com linfoma de células do manto; 1 paciente com linfoma de Burkitt; 1 paciente com linfoma do tipo MALT (tecido linfoide associado à mucosa); 1 paciente com doença linfoproliferativa pós-transplante; 2 pacientes com linfoma não Hodgkin de células $B$ de alto grau; 1 paciente com linfoma não Hodgkin de células $B$ de baixo grau; 1 paciente linfoma de Hodgkin; e 12 pacientes com linfoma não Hodgkin de células $B$, sem outra especificação. Conclusão: $\mathrm{A}$ imunofenotipagem por citometria de fluxo complementa os achados do estudo anatomopatológico/ imunoistoquímico, permitindo um diagnóstico hematopatológico rápido e preciso das doenças linfoproliferativas.

Descritores: Linfoma; Transtornos linfoproliferativos/diagnóstico; Imunofenotipagem; Citometria de fluxo; Imunoistoquímica

\section{INTRODUCTION}

Lymph node neoplasms often affect lymph nodes, the spleen, mucosa-associated lymphoid tissues, the skin, or non-lymphoid solid organs, resulting in tumors and enlarged organs. The diagnosis of lymphoproliferative diseases is made by pathology and immunohistochemistry of lymph nodes, which are the gold standard. These approaches demonstrate tissue structure and the classification of the type of lymphoma. These procedures, however, are time consuming and invasive; furthermore, some tissues are difficult to access.

Fine needle aspiration biopsy (FNAB) is often the first investigation (screening) for the differential diagnosis among benign/reactional and malignant tumors in cases of enlarged lymph nodes. It is a fast, simple, safe, and only slightly invasive technique for gathering well-preserved cells for studies.
FNAB may be used not only in tissue biopsies for pathology, but also as a technique for obtaining tissue specimens for other studies, including flow cytometry immunophenotyping, ${ }^{(1,2)}$ because of its high positive predictive value. Several studies have been proposed for establishing the reliability of FNAB in the diagnosis of lymphoproliferative diseases ${ }^{(3-9)}$ (Chart 1$)$.

Chart 1. Advantages and disadvantages of fine needle aspiration biopsy and pathological examination by lymph node biopsy in diagnosis of lymphoproliferative diseases

\begin{tabular}{|lcc|}
\hline & Advantages & Disadvantages \\
\hline Biopsy & Adequate study of histological architecture & Traumatic procedure \\
& & High relative cost \\
& Limited access in some & tissues \\
& & Time for results (between 10 \\
& and 15 days) \\
FNAB & Minimum trauma & Loss in observation of \\
& architectural pattern \\
& Low cost & \\
\hline
\end{tabular}

FNAB: fine needle aspiration biopsy.

Immunological marker analysis of lymph nodes based on flow cytometry immunophenotyping has progressed rapidly in the last few decades, going from restricted use in research to routine use in laboratory diagnoses. This has become possible mainly by the wide availability of flow cytometers and the significant amount of monoclonal antibodies for rapidly detecting membrane and intracellular antigens in different cell suspensions $^{(10,11)}$.

The immunophenotyping study of lymphoproliferative processes is used for distinguishing benign reactions and malignancies; it identifies monoclonality - mainly of B cells where there is restriction of one of the light immunoglobulin chains (Figure 1). Besides diagnosis, flow cytometry immunophenotyping is also applied for classifying the types and subtypes of lymphoproliferative diseases ${ }^{(12-14)}$.

The current classification of lymphoproliferative diseases (World Health Organization) ${ }^{(14)}$ emphasizes histologic, clinical, cytologic, immunophenotypic, and genotypic aspects for diagnosing and defining the prognosis of lymphoproliferative diseases. Thus, new highly specific markers are described on an ongoing basis to improve the diagnosis and to yield information about the prognosis of these diseases; monoclonal antibody panels may include these new markers depending of the needs of clinical investigation ${ }^{(15-17)}$.

High quality smears are useful, since a differential diagnosis may be made based on the nature of cells (monomorphic; polymorphic; small, medium or large 


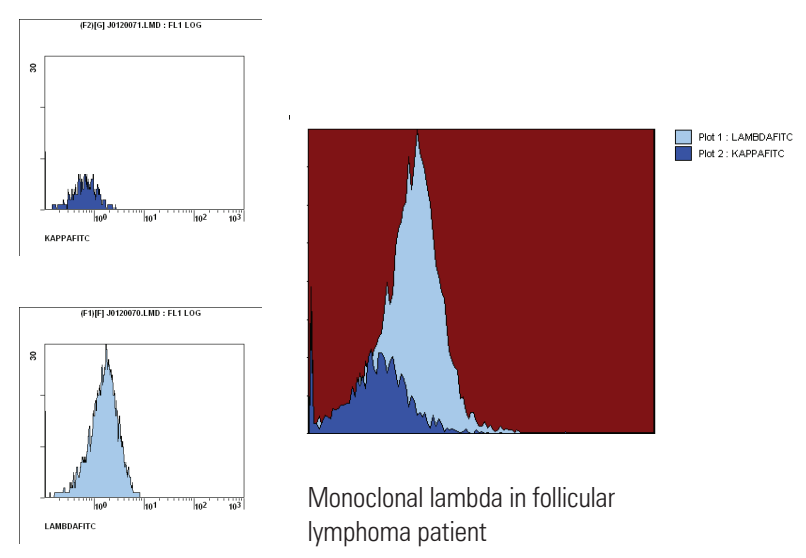

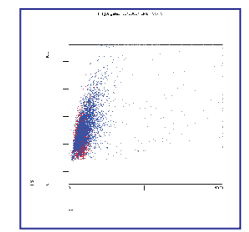

FS vs SS

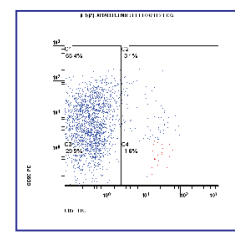

CD5FITC vs CD19PC5

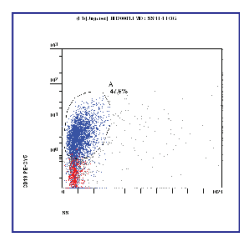

CD19PC5 vs SS

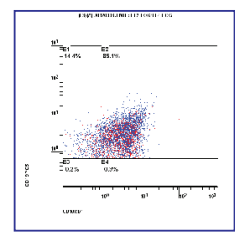

CD10PE vs CD19PC5

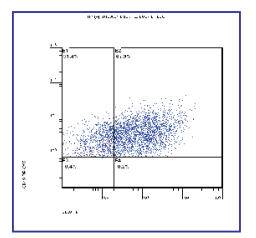

CD20FITC vs CD19PC5

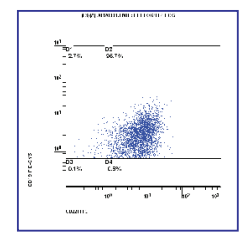

CD22FITC vs CD19PC5
Source: Laboratory of Special Techniques, Flow Cytometry Unit, Hospital Israelita Albert Einstein

Figure 1. Flow cytometry analysis of axillary lymphadenomegaly of patient with follicular lymphoma.

sized). Attention should be given to significantly hemodiluted materials, because proliferative cases may be mistakenly diagnosed as reactional.

The immediate morphological evaluation of specimens after fine needle aspiration may lead to a second FNAB or to a lymph node biopsy to obtain a specimen with more adequate cellularity ${ }^{(1,6,16,18,19)}$.

B cells comprise about $40 \%$ and $\mathrm{T}$ cells comprise about $55 \%$ of normal lymph nodes. The subtype CD4 predominates among CD3+ cells, and the CD4/CD8 ratio is over 4 . The frequency of natural killer cells in normal lymph nodes is very low (about $1 \%$ ). On the other hand, the tonsils are lymphoid organs in which $\mathrm{B}$ cells $(\mathrm{CD} 19+)$ predominate; the remaining cells are $\mathrm{CD} 3+$ with a predominance of the CD4 subtype, as in lymph nodes ${ }^{(20,21)}$.

B cell lymphomas are the majority among nonHodgkin lymphomas; in such cases, establishing cell clonicity - by restriction of one of the $\kappa$ (kappa) or $\lambda$ (lambda) light chains - is generally the key to define

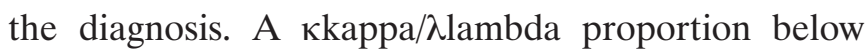
0.5 or over 3.0 suggests the presence of a clonal B cell population in peripheral blood, bone marrow, lymph nodes, the spleen, or other tissues with larger numbers of mature B lymphocytes ${ }^{(18)}$.

\section{OBJECTIVE}

Thepurposeofthisstudywastodemonstratetheadvantages of correlating flow cytometry immunophenotyping and pathology/immunohistochemistry of enlarged lymph nodes and/or nodules in the diagnosis of lymphoproliferative diseases.

\section{METHODS}

A retrospective study was made of 157 biopsy or fine needle aspiration specimens of lymph nodes or nodules obtained from 142 patients from 1999 to 2009; the specimens were sent simultaneously to the Flow Cytometry Unit and the Pathology Unit of the Israelita Albert Einstein Hospital, São Paulo, SP.

\section{Pathology/immunohistochemistry and cytology}

Biopsies or FNAB of lymph nodes or nodules were done in all patients for histologic and immunohistochemical diagnosis. The hematologic and laboratory routine practices were not altered or interfered with for this study.

Pathologists at our hospital usually have three moments to evaluate fresh tissue samples: during ultrasonography for FNABs, during computed tomography for guided needle biopsies, and during intraoperative freeze sections in the surgical theater.

Pathologists promptly examined FNABs specimens of lymph node/masses to establish cell representativeness; before tissue fixation of the specimens in $95 \%$ alcohol), the material was transferred to a tube containing ethylenediaminetetraacetic acid (EDTA) and $2 \mathrm{~mL}$ of a RPMI culture medium (RPMI 1640, developed at the Roswell Park Memorial Institute). Flow cytometry immunophenotyping took place within 6 hours of obtaining the specimen, which precluded the need for fixation.

For the biopsies, pathologists selected representative samples of fresh specimens for tissue fixation $(10 \%$ formaldehyde). The specimens were then transferred to a tube containing EDTA, and flow cytometry immunophenotyping was done similarly to the FNAB cases.

In the pathology laboratory, smears and cell centrifugates of FNAB specimens were routinely prepared 
for cytology; the Papanicolaou and Giemsa fixation were used. Biopsies went through routine histologic preparation and the slides were hematoxylin-eosin stained.

Immunohistochemistry consisted of placing the specimens on glass slides previously prepared with a polyD-Lysine adhesive (Sigma, St. Louis, MO, US, code P7886) and kept in an oven at $60^{\circ} \mathrm{C}$ for 4 hours. Deparaffining was done with repeated xylol baths, absolute ethyl alcohol, and washing with a buffered saline solution, a phosphate buffer solution (PBS), and blockage of endogenous activity with a $3 \% \mathrm{H} 2 \mathrm{O} 2$ solution. Antigenic recovery was attained by heat or the enzyme method. After recovery of the epitopes, the slides were incubated with the primary antibodies for 12 to 18 hours at $4^{\circ} \mathrm{C}$ at appropriate dilutions for each antibody. The slides were then washed again with PBS and incubated for 60 minutes with the respective secondary antibodies. Polymer detection systems were then applied. The slides were processed by a treatment with 3,3'-diaminobenzidine (DAB, Sigma, St. Louis, MO, US, code. D5637), $\mathrm{H} 2 \mathrm{O} 2$ (final concentration $=0.2 \%$ ), Mayer hematoxylin counterstained, and mounted with histologic resin. Pathologists evaluated all assays with common microscopy; the immunohistochemical reaction controls were positive.

An initial panel consisted of the following primary antibodies: CD20 (clone L26), CD3 (polyclonal), CD10 (clone 56C6), Bcl-2 (clone Bcl-2-100), Bcl-6 (clone lymph node22), CD5 (clone RTB-CD5), CD23 (clone 1B12), cycline D1 (clone SP4), Ki-67 (clone SP6), CD30 (clone Ber-H2), Epstein Barr virus (EBV - clone CS.1-4), and CD15 (clone BY87). This panel was increased by adding the following antibodies, as needed: CD138 (clone MI15), Kappa (polyclonal), Lambda (polyclonal), CD4 (clone 1F6), CD8 (clone C8/144B), CD43 (clone DF-T1), CD56 (clone 123C3), myeloperoxidase (polyclonal), granzyme B (polyclonal), TIA-1 (clone C-20), multiple myeloma-1/ interferon regulatory factor-4 (MUM1/IRF4 - clone MUM 1P), and terminal deoxynucleotidyl transferase (TdT - polyclonal), cytokeratins (clone AE1/AE3), Melan A (clone M27C10), protein S-100 (polyclonal), and HMB45 (clone HMB45).

Pathologists carried out the final histologic evaluation under a common light microscope, based on the 2001 and 2008 tumor classification systems of the World Health Organization (WHO), as recommended in the literature ${ }^{(14)}$.

\section{Flow cytometry immunophenotyping}

FNAB samples were placed in a collecting medium (Vitrocell), and lymph node/mass samples were imbibed in a saline solution or a collecting medium (RPMI, Vitrocell). Cells were first counted in a Neubauer chamber. The slides were prepared in Cytospin and colored with a Rosenfeld dye for cytomorphology. The $7-\mathrm{AAD}$ cell viability assay was used. After the morphologic analysis, the specimens were pipette in $12 \times 75 \mathrm{~mm}$ tubes depending on the sample volume and the number of cells. The specimens were then PBS (phosphate buffer) washed before marking with monoclonal antibodies. These were obtained from several manufacturers: Beckman Coulter (BC), Becton Dickinson (BD), IQ Products (IQP), Immunotech (IM).

Basic screening of the phenotypic profile of the specimens consisted of applying a panel with the following antibodies: anti-CD2(BC), anti-CD3(BC), anti-CD4(BC), anti-CD8(BC), anti-CD14(BC), antiCD15(IM), anti-CD19(BC), anti-CD30(IM), antiCD34(IM), anti-CD45(IM), anti-Kappa (Dako), and anti-Lambda (Dako) ${ }^{(22)}$.

If clonality was present, a complete antibody panel was used, including a panel for the B cell proliferative disease: CD2(BC), CD3(BC), CD5(IM), CD7(BC), CD10(IM), CD11c(IM), CD20(IM), CD22(IM), CD23(Dako), CD25(BC), CD38(IM), CD79b(IM), CD103(IQP), FMC-7(IM), HLA-DR(IM), IgM(Dako), $\operatorname{IgD}$ (Dako), and $\operatorname{IgG}$ (Dako).

Other panels were used, as follows:

- panel for $\mathrm{T}$ cell lymphoproliferative disease: CD1a(IM), CD2(BC), CD3(BC), CD5(IM), CD7(BC), CD10(IM), CD20(IM), CD38(IM), CD56((IM), TCR Alfa/Beta(IM), TCR Gamma/Delta(IM);

- panel for multiple myeloma and associated diseases: CD19(PC5), CD20(CD5), CD33(IM), CD38(IM), CD45(IM), CD56(IM), CD117(IM), HLA-DR(IM), and intracytoplasmatic markers for Kappa, Lambda, IgM, IgG, IgD, and IgA.

After marking with monoclonal antibodies, cells were incubated during 15 minutes at room temperature and away from light. A hemolytic buffer (ammonium chloride) was applied during 15 minutes at room temperature for lysis of red blood cells.

Specimens were washed three times with PBS and fetal bovine serum, and incubated during one hour in a water bath at $37^{\circ} \mathrm{C}$ for surface marking into light and heavy chain immunoglobulins. The IntraPrep kit (Beckman Coulter) was used for intracytoplasmatic marking. Data gathering and analysis was done in an EPICS XL-MCL and FC-500 (Beckman Coulter) flow cytometer. Analyses were interpreted based on the resulting histograms together with cytomorphology of the specimens, according to the tumor classification system of the $\operatorname{WHO}(2001$ and 2008) or others recommended previously in the literature ${ }^{(14)}$.

The combined results of lymph node analysis by FNAB cytology and pathology/immunohistochemistry were compared with the results of flow cytometry 
immunophenotyping. Sensitivity and specificity were used as parameters for assessing the performance of flow cytometry immunophenotyping relative to pathology (the gold standard).

Sensitivity was calculated to assess the proportion of diseases subjects that tested positive, and specificity was calculated to assess the proportion of disease-free subjects that tested negative. The positive predictive value was calculated to assess the probability of a subject having the disease when tested positive, and the negative predictive values was calculated to assess the probability of a subject not having the disease when tested negative.

\section{RESULTS}

There were 157 specimens of 142 patients during the period from 1999 to 2009, of which 75 were male and 67 were female; the mean age was 55 years (ranging from 4 to 92 years).

The procedures for obtaining the specimens consisted of biopsies in 119 patients, FNAB in 16 patients, and FNAB followed by biopsy in 7 patients.

The sites for 145 lymph node specimens were the neck, inguinal, axillary, mediastinal, peripancreatic, paraaortic, and juxtacarotid regions; the sites of 12 tumor mass samples were the spleen, kidney, small intestine, lung, ischium, parotid, scalp, and nasopharynx. There were more than one specimens in 12 patients because of different procedures (for instance, FNAB specimens followed by biopsy specimens), different sites obtained at the same time, different years in a single patient, or duplication of specimens (Table 1).

To investigate the efficacy of associating flow cytometry immunophenotyping with pathology for accurate diagnoses, we assessed the agreement percentage between the two techniques for each disease group in the study (Figure 2).

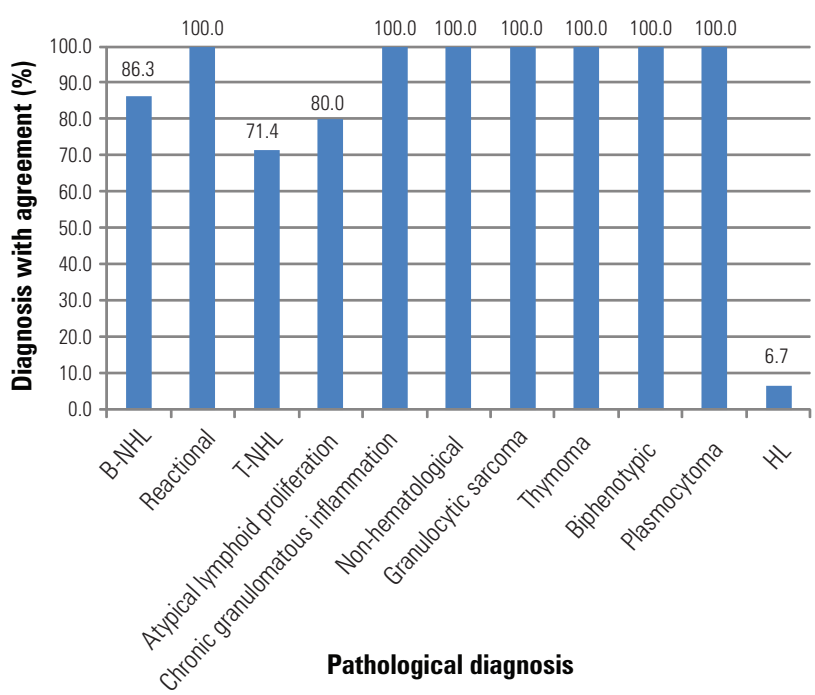

B-NHL: B-cell non-Hodgkin lymphoma ( $n=73)$; reactional: reactional lymphoid hyperplasia $(n=26)$; T-NHL: T-cell non-Hodgkin lymphoma ( $n=7)$; Atypical lymphoid proliferation $(n=5)$; Chronic granulomatous inflammation $(n=5)$; Non-hematological: includes carcinomas, adenocarcinomas and melanoma $(n=5)$; Biphenotypic: biphenotypic leukemia ( $n=1)$; HL: Hodgkin's lymphoma $(n=15)$; Granulocytic sarcoma $(n=2)$ : Thymoma $(\mathrm{n}=2)$; Plasmocytoma $(\mathrm{n}=1)$.

Figure 2. Percentage of diagnosis with agreement in pathological examination and flow cytometry immunophenotyping per studied group.

The 142 study patients were classified according to the diagnosis of the disease (Table 1). The bars show the percentage of agreement in diagnosis by each technique (Figure 2).

Interestingly, agreement was above $80 \%$ in 9 of 11 disease groups; it was above $70 \%$ in one group. Only the diagnosis of Hodgkin's lymphoma (LH) was mostly discordant, which has been predicted in the literature, as will be discussed below.

Of 73 patients diagnosed with $B$ cell nonHodgkin's lymphoma in pathology $(51.4 \%$ of patients in this study), the agreement with flow cytometry immunophenotyping was $86.3 \%$. There was poor diagnostic agreement in seven patients with $\mathrm{T}$ cell non-Hodgkin's lymphoma ( $4.9 \%$ of patients in this

Table 1. List of patients per pathological diagnosis and types of specimen collection

\begin{tabular}{|c|c|c|c|c|c|}
\hline Pathological diagnosis & Number of patients & Patients \% & Number of FNAB & Number of FNAB + biopsy & Number of biopsies \\
\hline B-NHL & 73 & 51.41 & 5 & 4 & 64 \\
\hline Reactional & 26 & 18.31 & 4 & 0 & 22 \\
\hline T-NHL & 7 & 4.93 & 0 & 0 & 7 \\
\hline Atypical lymphoid proliferation & 5 & 3.52 & 3 & 0 & 2 \\
\hline Chronic granulomatous inflammation & 5 & 3.52 & 4 & 0 & 1 \\
\hline Non-hematological & 5 & 3.52 & 0 & 0 & 5 \\
\hline Biphenotypic & 1 & 0.70 & 0 & 0 & 1 \\
\hline Plasmocytoma & 1 & 0.70 & 0 & 0 & 1 \\
\hline $\mathrm{HL}$ & 15 & 10.56 & 0 & 3 & 12 \\
\hline Total & 142 & 100 & 16 & 7 & 119 \\
\hline
\end{tabular}

FNAB: fine needle aspiration biopsy; B-NHL: B-cell non-Hodgkin lymphoma; T-NHL: T-cell non-Hodgkin lymphoma; HL: Hodgkin's lymphoma. 
study). The agreement between pathology and flow cytometry immunophenotyping was $80 \%$ in the five patients with atypical lymphoid proliferation. Flow cytometry immunophenotyping was completely effective in the diagnosis of reactional hyperplasia, granulomatous inflammation, non-hematologic cancer, granulocytic sarcoma, thymoma, and individual cases of biphenotypic leukemia and plasmacytoma $(100 \%$ agreement with pathology).

Figure 3 shows the diagnoses of patients according to pathology.

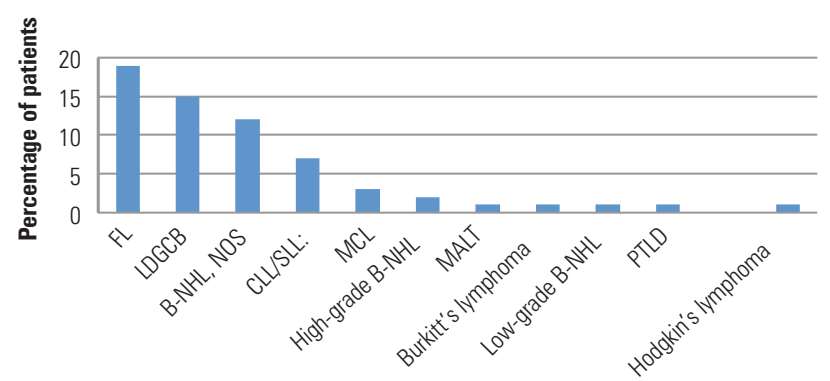

Source: Department of Pathology - Hospital Israelita Albert Einstein

Figure 3. Distribution of diagnosis agreement in percentage of patients per subtype of lymphoma.

The distribution according to subtypes in 63 concordant cases of non-Hodgkin's lymphoma was as follows:

- follicular lymphoma (LF): 19 patients (Figure 4A and $4 \mathrm{~B}$ );

- large B cell diffuse lymphoma: 15 patients;

- lymphocytic lymphoma/chronic lymphocytic leukemia (LLC/ LL): 7 patients;

- mantle cell lymphoma: 3 patients;

- Burkitt's lymphoma: 1 patient;

- MALT lymphoma (mucosa-associated lymphoid tissue): 1 patient;

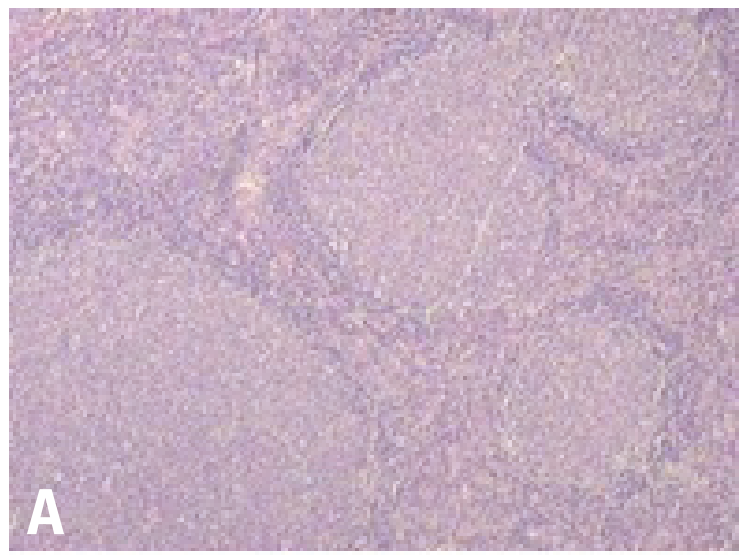

Source: Departament of Hematology - Hospital Israelita Albert Einstein
- post-transplantlymphoproliferative disease(PTLD): 1 patient;

- high grade B cell non-Hodgkin's lymphoma: 2 patients;

- low grade B cell non-Hodgkin's lymphoma: 1 patient;

- B cell non-Hodgkin's lymphoma, not otherwise specified: 12 patients;

- Hodgkin's lymphoma: 1 patient (Figure 5A and 5B).

Discordant diagnoses between pathology and flow cytometry immunophenotyping comprised 27 patients $(19.0 \%)$ in 30 specimens $(19.1 \%)$, as shown on table 2.

Table 2. General distribution of non-agreed diagnoses per type of definite pathological examination.

\begin{tabular}{lcc}
\hline Diagnoses per pathology & Patients (\%) & Samples (\%) \\
\hline Hodgkin's lymphoma & $14(51.85)$ & $17(56.7)$ \\
B-cell non-Hodgkin lymphoma & $10(37)$ & $10(33.3)$ \\
T-cell non-Hodgkin lymphoma & $02(7.4)$ & $2(6.7)$ \\
Reactional lymphoid hyperplasia & $01(3.7)$ & $01(3.3)$ \\
\hline
\end{tabular}

The following subtypes were found when the diagnoses of non-Hodgkin's lymphoma made with flow cytometry immunophenotyping and pathology did not agree:

- B cell lymphoma rich in T cells and histiocytes: 2 patients;

- large B cell diffuse lymphoma: 6 patients;

- precursor B cell lymphoblastic lymphoma / lymphoblastic leukemia: 1 patient;

- marginal zone (MALT) B cell non-Hodgkin's lymphoma with focal involvement of lymph nodes: 1 patient

The sensitivity test value for flow cytometry immunophenotyping compared to pathology (gold

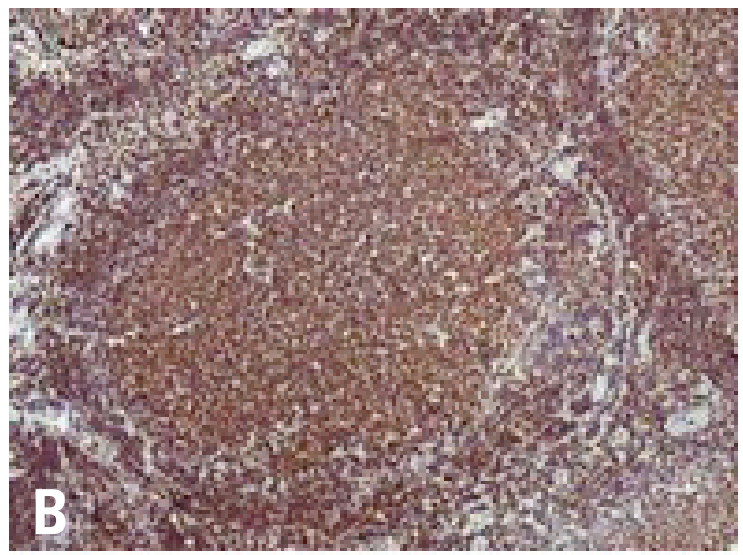

Figure 4. Immunohistochemical panel for diagnosis of follicular lymphoma. (A) Histological features of follicular lymphoma with identification of neoplastic follicle architecture (200x, hematoxylin-eosin); (B) Bcl-2 positivity in immunohistochemical examination in a neoplastic follicle (400X). 

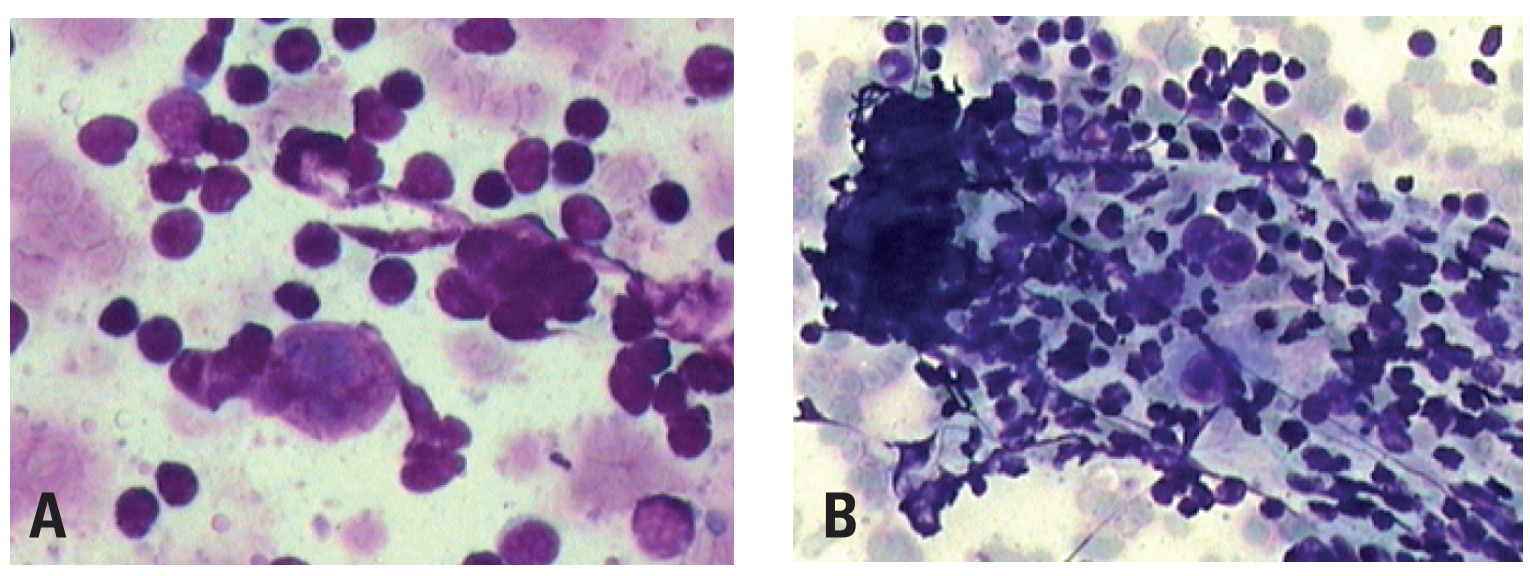

Source: Department of Pathology - Hospital Israelita Albert Einstein.

Figure 5. Fine needle aspiration biopsy showing, in cytology, cells with voluminous nuclei and evident nucleoli (A), sometimes multinucleated (B) diagnostic of Hodgkin lymphoma (400x and 200x, respectively, hematoxylin-eosin).

standard) was 0.77 ; the specificity value was 0.97 . The positive predictive value was 0.77 , and the negative predictive value was 1.00 .

\section{DISCUSSION}

The traditional technique of choice for diagnosing lymph node diseases has been histopathology of paraffin-included tissues. Immunohistochemistry is an important tool for analyzing biopsies of lymph nodes and other tissues; cell morphology and tissues architecture are preserved, and immunophenotypic analysis of histological sections are possible ${ }^{(23,24)}$. Detecting specific antigens in lymphoid cells is fundamental for classifying tumors, assessing the outcome, and identifying specific targeted therapy ${ }^{(13,14)}$. However, pathology of immunohistochemical results in routine laboratory work has its limits: the analysis may be subjective, reproducibility is limited, and the process is time-consuming. Inter- and intra-observer variability is high because so many factors may interfere with the processing of specimens and interpretation of results. Thus, lack of consensus in quantifying antigen expression and defining positive and negative results in poor reproducibility. Cytomorphological assays and flow cytometry immunophenotyping overcome some of these hurdles by providing faster diagnoses, quantitative and qualitative analysis of cell antigens, and multiparametric analyses ${ }^{(2,7,17,18)}$. However, flow cytometry also has its limits: variability in antigenic signature expression; loss of cells during the pre-analytical process; specimen preparation issues; work with fresh specimens; and availability of sufficient neoplastic cells. Large cell lymphoma cells may be lost in the preparation process because of cell frailty. According to the literature, a negative result does not exclude malignancy ${ }^{(11,18,19,23)}$.

FNAB is a minimally invasive procedure for which cytomorphologicalanalysiscombinedwithflowcytometry immunophenotyping are important tools, which are able to rapidly differentiate lymphoproliferative diseases from reactional lymphoid hyperplasia in most cases of enlarged lymph nodes ${ }^{(20,23,25)}$.

In our study, the diagnosis by flow cytometry immunophenotyping and pathology differed in 27 cases; this occurred more often when diagnosing Hodgkin's lymphoma in 14 patients out of 15 patients with positive pathology for this disease (51.85\% of the total number of discordant cases), in 17 specimens $(56.7 \%)$.

Although flow cytometry is useful for diagnosing several hematopoetic neoplasms, and may often detect small cell populations ( $<0.01 \%$ of leukocytes), it is a limited technique for the diagnosis of Hodgkin's lymphoma involving lymph nodes. Many studies on flow cytometry immunophenotyping in Hodgkin's lymphoma have shown changes in reactional lymphocytes, such as the CD4/CD8 ratio in T cells; however, this technique fails to detect Reed Sternberg cells, especially because of their large volume ${ }^{(26)}$. In 2009, Wood described a highly sensitive and specific technique based on flow cytometry using nine colors and three lasers for diagnosing classic Hodgkin's lymphoma ${ }^{(27)}$.

Flow cytometry failed to diagnose non-Hodgkin's B lymphoma in ten patients of our sample. In these cases, there was partial distribution of anomalous cells in lymphoid tissues in two patients, which affected neoplastic cell representation. In two cases, the final diagnosis was large B cell diffuse lymphoma rich in $\mathrm{T}$ cells/histiocytes, where those few detected 
neoplastic cells are spread out in a rich background of $\mathrm{T}$ lymphocytes and histiocytes; furthermore, the cells are large and more fragile compared to other lymphocytes. Thus, they are not well represented, which may mask flow cytometry analysis. Meda et al. ${ }^{(28)}$ and Verstovsek et al ${ }^{(1)}$ also reported this finding. They are often wrongly characterized as a polyclonal population because of significant contamination by residual normal cells. Therefore, a flow cytometry immunophenotyping result showing no evidence of malignancy did not exclude a cancer; in these situations, a detailed cytomorphological exam is required, as demonstrated in the literature ${ }^{(9,29)}$.

According to Meda et al. ${ }^{(28)}$ and Zardawi et al., ${ }^{(18)}$ if $\kappa$ and $\lambda$ light chains are not restricted, further evidence of clonal proliferation may be investigated, such as major antigen proliferation (CD19, CD20) in specific tissues (over $85 \%$ ), $\mathrm{CD} 10 \geq>18 \%$ or $\mathrm{CD} 20+\mathrm{CD} 5+\geq>35 \%$.

Among other studies, Martins et al. ${ }^{(7)}$ conducted a retrospective study of 627 lymph node FNAB specimens and underlined the importance of cytomorphological analysis for the diagnosis of large cell non-Hodgkin's lymphoma.

In three of our patients, the specimens consisted of necrotic material, which was frail or sparse for flow cytometry immunophenotyping; the specimen with sparse material was obtained in a bone biopsy, and was not representative of the neoplasm. Representativeness of malignancy was lost in three patients, and flow cytometry immunophenotyping diagnosis was not possible (in one, the PCR technique for B clonality was used to supplement the study); furthermore no distinct representative $\operatorname{IgH}$ loci monoclonal rearrangement band was found, which demonstrated the paucity of cells in the specimen. The presence of necrosis, accelerated tumor growth, and bone, affected pre-analytical processing, thereby interfering with cell viability for analysis in the cytometer; this again has been reported in the literature ${ }^{(19,23)}$.

In $\mathrm{T}$ cell lymphomas, cell clonality may only be characterized if antigenic expression of a $\mathrm{T}$ lineage marker is absent. A demonstration of T clonality may be done using PCR, the Southern Blot molecular biology technique, or flow cytometry for clonality detection in the $\mathrm{V} \beta$ family with simultaneous analysis of more than 20 monoclonal antibodies - a technique that is not available in Brazil.

In our study, flow cytometry was more specific than sensitive in diagnostic agreement, a result of poor agreement in patients with Hodgkin's lymphoma, ${ }^{(14,15)}$ and in ten patients with large cell diffuse lymphoma, as described previously ${ }^{(10)}$. These factors also affected the global positive predictive value.

Immunohistochemistry is an important tool in biopsies of lymph nodes and other tissues; it is possible to analyze the immunophenotype of histological sections where identification of the tissue architecture is also possible ${ }^{(30)}$. For example, identifying CD5 antigen expression in some lymphomas, such as between the small cell lymphocytic lymphoma/chronic lymphocytic leukemia (LL/CLL) and the mantle cell lymphoma (ML), which are two types of lymphoproliferative diseases that progress differently, thereby requiring a correct definition. These cases require investigating and charactering the D1 cyclin marker, which is found in 70 to $80 \%$ of mantle cell lymphoma cases ${ }^{(15)}$ - a technique that is done successfully only with immunohistochemistry. Detection is also possible of the typical $\mathrm{t}(11: 14)$ of the mantle cell lymphoma in classic cytogenetics, fluorescent in situ hybridization (FISH), and reverse transcription polymerase chain reaction (RT-PCR).

In mature $\mathrm{B}$ cell lymphomas, the main differential diagnosis to be made among those that are positive for the CD10 marker is between the follicular lymphoma, the large cell diffuse lymphoma, and Burkitt's lymphoma. Demonstrating histologically the Bcl-2 marker helps identify neoplastic follicles in follicular lymphomas and differentiate them from reactional follicles in follicular lymphoid hyperplasia. Identifying Bcl-2 is difficult in flow cytometry, which however may differentiate follicular lymphomas from lymphoid hyperplasia by testing clonality in the $\kappa$ and $\lambda$ ratio ${ }^{(16,21,31)}$.

Diagnostic centers that currently provide these technologies as supplementary diagnostic tools reduce the limitations of each method, add speed, and further choices for staging and defining the most appropriate treatment.

\section{CONCLUSION}

We have been able to show that in several situations, for many hematologic diseases, flow cytometry associated with cytomorphology and immunohistochemistry made it possible to diagnose and differentiate reactional processes from neoplasms, and to subclassify lymphoproliferative diseases.

In our experience with the majority of suspected cases of lymphoproliferative diseases, flow cytometry data supplemented the findings of cytomorphology, immunohistochemistry (FNABs) and biopsy specimens.

\section{REFERENCES}

1. Verstovsek G, Chakraborty S, Ramzy I, Jorgensen JL. Large B-cell lymphomas: fine-needle aspiration plays an important role in initial diagnosis of cases which are falsely negative by flow cytometry. Diagn Cytopathol. 2002;27(5):282-5.

2. Dong $H Y$, Harris NL, Preffer Fl, Pitman MB. Fine-needle aspiration biopsy in the diagnosis and classification of primary and recurrent lymphoma: a retrospective analysis of the utility of cytomorphology and flow cytometry. Mod Pathol. 2001;14(5):472-81. 
3. Nicol TL, Silberman M, Rosenthal DL, Borowitz MJ. The accuracy of combined cytopathologic and flow cytometric analysis of fine-needle aspirates of lymph nodes. Am J Clin Pathol. 2000;114(1):18-28.

4. Caraway NP. Strategies to diagnose lymphoproliferative disease disorders by fine-needle aspiration by using ancillary studies. Cancer. 2005;105(6):432-42

5. Sigstad E, Dong HP, Davidson B, Berner A, Tierens A, Risberg B. The role of flow cytometric immunophenotyping in improving the diagnostic accuracy in referred fine-needle aspiration specimens. Diagn Cytopathol. 2004;31(3):159-63.

6. Costa FPS, Pereira FG, Vassalo J, Freitas LLL, Lorand-Metze I. A utilidade da citologia por punção com agulha fina aliada à imunofenotipagem no diagnóstico dos linfomas não-Hodgkin. Rev Bras Hematol Hemoter. 2005;27(1):16-20.

7. Martins MR, Santos GC. Fine-needle aspiration cytology in the diagnosis of superficial lymphadenopathy: a 5-year Brazilian experience. Diagn Cytopathol. 2006;34(2):130-4.

8. Gupta R, Naseem S, Kashyap R, Paul L. Role of fine-needle aspirate immunophenotyping by flow cytometry in rapid diagnosis of lymphoproliferative disorders. Diagn Cytopathol. 2007;35(7):381-5

9. Jorgensen, JL. State of the Art Symposium: flow cytometry in the diagnosis of lymphoproliferative disorders by fine-needle aspiration. Cancer. 2005;105(6):443-51.

10. Szczepa ski T, van der Velden VH, van Dongen JJ. Flow cytometric immunophenotyping of normal and malignant lymphocytes. Clin Chem Lab Med. 2006;44(7):775-96.

11. Jennings $C D$, Foon KA. Recent advances in flow cytometry: application to the diagnosis of hematologic malignancy. Blood. 1997;90(8):2863-92.

12. Wood BL, Arroz M, Barnett D, DiGiuseppe J, Greig B, Kussick SJ, et al. 2006 Bethesda International Consensus recommendations on the immunophenotypic analysis of hematolymphoid neoplasia by flow cytometry: optimal reagents and reporting for the flow cytometric diagnosis of hematopoietic neoplasia. Cytometry B Clin Cytom. 2007;72 Suppl 1:S14-22.

13. Harris NL, Jaffe ES, Diebold J, Flandrin G, Muller-Hermelink HK, Vardiman J, et al. World Health Organization classification of neoplastic diseases of the hematopoietic and lymphoid tissues: report of the Clinical Advisory Committee Meeting. J Clin Oncol. 1999;17(12):3835-49.

14. Swerdlow SH, Campo E, Harris NL, Jaffe ES, Pileri SA, Stein H, et al. World Health Organization Classification of Tumours of Haematopoietic and Lymphoid Tissues. 4th ed. Lyon: IARC Press; 2008.

15. Elnenaei MO, ,Jadayel DM, Matutes E, Morilla R, Owusu-Ankomah K, S et al. Cyclin D1 by flow cytometry as a useful tool in the diagnosis of B-cell malignancies. Leuk Res. 2001;25(2):115-23.

16. Cornfield DB, Mitchell DM, Almasri NM, Anderson JB, Ahrens KP, Dooley EO, et al. Follicular lymphoma can be distinguished from benign follicular hyperplasia by flow cytometry using simultaneous staining of cytoplasmatic Bcl-2 and cell surface CD20. Am J Clin Pathol. 2000;114(2):258-63

17. Colorado M, Cuadrado MA, Insunza A, Mazorra F, Acinas 0, Iriondo A. Simultaneous cytomorphologic and multiparametric flow cytometry analysis on lymph node sample is faster than as valid as histopathologic study to diagnose most non-Hodgkin lymphomas. Am J Clin Pathol. 2010;133(1):83-91.

18. Zardawi IM, Jain S, Bennett G. Flow-cytometric algorithm on fine-needle aspirates for the clinical workup of patients with lymphadenopathy. Diagn Cytopathol. 1998;19(4):274-8.

19. Gong JZ, Williams DC Jr, Liu K, Jones C. Fine-needle aspiration in non-Hodgkin lymphoma: evaluation of cell size by cytomorphology and flow cytometry. Am J Clin Pathol. 2002;117(6):880-8.

20. Küppers R. Mechanisms of B-cell lymphoma pathogenesis. Nat Rev Cancer. 2005;5(4)251-62.

21. Wood BL, Borowitz MJ. The flow cytometric evaluation of hematopoietic neoplasia. In: McPherson RA, Pincus MR, editors. Henry's Clinical Diagnosis and Management by Laboratory Methods. 21st ed. Philadelphia, PA: Saunders; 2007. p. 599-616.

22. Martínez A, Aymerich M, Castillo M, Colomer D, Bellosillo B, Campo E, et al. Routine use of immunophenotype by flow cytometry in tissues with suspected hematological malignancies. Cytometry B Clin Cytom. 2003;56(1):8-15

23. Mayall F, Dray M, Stanley D, Harrison B, Allen R. Immunoflow cytometry and cell block immunohistochemistry in the FNA diagnosis of lymphoma: a review of 73 consecutive cases. J Clin Pathol. 2000;53(6):451-7.

24. Chan JK. Advances in immunohistochemistry:impact on surgical pathology practice. Semin Diagn Pathol. 2000;17(3):170-7.

25. Orfao A, Alameida J, Sanches ML, San Miguel JF. Immunophenotypic diagnosis of leukemic b-cell chronic lymphoproliferative disorders other than chronic lymphocytic leukemia. contemporary hematology. chronic lymphocitic leukemia: molecular, genetics, biology, diagnosis, and management. Totowa, NJ: G.B. Faguet. Human Press; 2004. p. 173-92.

26. Poppema S, Potters M, Emmens R, Visser L, van den Berg A. Immune reactions in classical Hodgkin's lymphoma. Semin Hematol. 1999;36(3):253-9.

27. Fromm JR, Thomas A, Wood BL. Flow cytometry can diagnose classical hodgkin lymphoma in lymph nodes with high sensitivity and specificity. Am J Clin Pathol. 2009;131(3):322-32.

28. Meda BA, Buss DH, Woodruff RD, Cappellari J0, Rainer RO, Powell BL, et al. Diagnosis and subclassification of primary and recurrent lymphoma. Am J Clin Pathol. 2000;113(5):688-99.

29. Sneige N, Dekmezian RH, Katz RL, Fanning TV, Lukeman JL, Ordoñez NF et al. Morphologic and immunocytochemical evaluation of 220 fine needle aspirates of malignant lymphoma and lymphoid hyperplasia. Acta Cytol. 1990;34(3):311-22

30. Chan JK. Advances in immunohistochemistry:impact on surgical pathology practice. Semin Diagn Pathol. 2000;17(3):170-7.

31. Laane E, Tani E, Björklund E, Elmberger G, Everaus $H$, Skoog $L$ et al. Flow cytometric immunophenotyping including Bcl-2 detection on fine needle aspirates in the diagnosis of reactive lymphadenopathy and non-Hodgkins lymphoma. Cytometry B Clin Cytom. 2005;64(1):34-42. 